5. Виборчий кодекс України. // База даних «Законодавство України». URL: https://zakon.rada.gov.ua/laws/show/396-20\#Text (дата звернення 16.02.2021).

6. Recommendation $\mathrm{CM} / \operatorname{Rec}(2017) 51$ of the Committee of Ministers to member States on standards for e-voting. Adopted by the Committee of Ministers on 14 June 2017 at the 1289th meeting of the Ministers' Deputies. URL: https://rm.coe.int/0900001680726f6f (дата звернення 14.02.2021).

DOI https://doi.org/10.30525/978-9934-26-045-2-12

\title{
ДЕЯКІ АСПЕКТИ ЗАСТОСУВАННЯ ПОНЯТЬ ЩДЕРЖАВНЕ УПРАВЛІННЯ» ТА «ПУБЛІЧНЕ УПРАВЛІННЯ І АДМІНІСТРУВАННЯ» В УКРАЇНІ
}

\author{
Сабурова Г. Б. \\ начальник відділу документування управлінської діяльності апарату \\ Полтавської обласної державної адміністращії \\ м. Полтава, Україна
}

Така галузь науки як «публічне управління і адміністрування» 3'явилась на терені інших наук в Україні порівняно недавно і посіла там гідне місце.

Передумовою iii виникнення та становлення був бурхливий розвиток новітніх інформаційних технологій, поступова інформатизація суспільства, прогресивний розвиток державної інформаційної політики, подальший розвиток демократичних засад громадянського суспільства, пов'язаний з процесами децентралізації, а також численні праці українських вчених та науковців.

Освітня галузь України не могла залишатись осторонь викликів часу. В багатьох закладах вищої освіти були створені кафедри публічного управління і адміністрування, на яких викладацьку та наукову діяльність 3 цього напрямку ведуть кандидати та доктори наук саме 3 державного управління. При деяких академіях, університетах та інститутах були відкриті аспірантури, які готують фахівців 3-го рівня вищої освіти за спеціальністю 281 - «Публічне управління і адміністрування» під керівництвом докторів наук саме 3 державного управління.

Слід відзначити також, що станом на 2019 рік для вищевказаної спеціальності спецкомісією МОН України начолі з проф. С.А.Чукут 
було розроблено, затверджено і запроваджено стандарт вищої освіти для підготовки фахівців 1-го рівня - бакалаврів 3 публічного управління і адміністрування, що є дуже своєчасним в плані забезпечення органів місцевого самоврядування та органів виконавчої влади регіонального рівня висококваліфікованими кадрами.

Нинішні суспільно-політичні перетворення в Україні, пов'язані з процесами децентралізації державної влади та подальшою імплементацією процесів диджиталізації у сферу публічних послуг, обумовили появу наукових публікацій з певними розбіжностями у підходах щодо сутності понять «державне управління», «публічне управління» i «публічне адміністрування» та висновками стосовно їх використання в теорії і повсякденній практиці.

Щодо тлумачення поняття «державне управління» ми поділяємо погляди Г.В. Атаманчука, який під державним управлінням розуміє практичний, організуючий та регулюючий вплив держави через систему своїх структур на суспільну і приватну життєдіяльність людей 3 метою ії упорядкування, збереження або необхідного перетворення, що спирається на іiї владну силу [1].

Слід зазначити, що для викладу поняття «державне управління» в англомовному варіанті науковці використовують два терміни «governance» та «government administration». Ми схильні вважати, що для відтворення поняття «державне управління» вживання англійського терміну «governance» $€$ найбільш прийнятним.

В наукових джерелах публічне управління об'єднує вплив на життедіяльність людей як 3 боку органів виконавчої влади, так i місцевого самоврядування та громадських організацій. Виходячи 3 цього, державне управління визнається складовою частиною публічного управління.

Науковці вказують на двоїстий характер публічного управління: 3 одного боку, народ, суспільство, громада $\epsilon$ об'єктом керування, підпорядкованим певним структурам (тоді це не $\epsilon$ суто публічним управлінням в нашому розумінні); з іншого боку, народ, суспільство, громада є суб'єктом управління (за умови володіння реальною владою), коли управління здійснюється самим народом, певною визначеною громадою на певному рівні $з$ характерними рисами самоорганізації і самокерованості у вирішенні всіх своїх питань (в нашому розумінні це i $\epsilon$ управлінням в публічному секторі).

Ми поділяємо думку багатьох науковців, що публічне адміністрування - це фактично надання публічних послуг поряд 3 виконанням окремих управлінських функцій, а сам термін 
«адміністрування» (у вузькому сенсі «розпорядництво») вважається нами одним із методів публічного управління.

Треба відзначити, що органи виконавчої влади загальної компетенції на виконання законів України про доступ до публічної інформації, про інформаційні запити та звернення громадян до певної міри відповідають задоволенню потреб громадянського суспільства в частині надання електронних послуг; відкритості та прозорості певних дій та управлінських рішень через свої web-портали та телекомунікаційні мережі; цьому також сприяє створення обласних контактних центрів, що реагують на звернення громадян, тощо. Але зважаючи на державно-управлінський характер діяльності апарату державного управління та 3 огляду на процеси децентралізації шляхом створення об'єднаних територіальних громад (ОТГ), повної відповідності діяльності органів виконавчої влади задоволенню потреб суспільства в численних адміністративних послугах i не має бути. Державне управління відзначається опрацюванням та створенням великих масивів офіційних службових документів, більша частина яких $\epsilon$ документами прямої дії, тобто підлягає обов’язковому виконанню.

Вважаємо за доцільне відзначити умовний розподіл публічного управління взагалі на державне управління, публічне адміністрування та управління в публічному секторі (приватний сектор в даних тезах не розглядається).

У своїй публікації «Зміна співвідношення понять «державне управління», «публічне управління» та «публічне адміністрування»у системі суспільно-політичних трансформацій» Н.В.Філіпова наголошує на тому, що ці поняття не слід використовувати як аналогічні та зазначає, що саме публічне адміністрування поєднує публічне та державне управління [2]. Ми не маємо сумніву в тому, що державне i публічне управління - це різні речі, не дивлячись на деяку їх спорідненість, та поділяємо думку автора щодо того, що «адміністрування» є загальним для цих двох понять, але водночас звертаємо увагу на той факт, що «адміністрування» $є$ лише одним із елементів діяльності органів виконавчої влади, в той час як в публічному секторі питома вага цього поняття є набагато більшою.

В публікації О.В.Митяя і О.М.Світового «Дослідження понять «державне управління» i «публічне адміністрування» « основна увага зосереджена на визначенні поняття «публічне адміністрування» з точки зору різних областей знань, словників та енциклопедичної літератури [3]. Ми не можемо погодитись з висновками авторів цієї публікації щодо твердження, що «публічне адміністрування» і $\epsilon$ державним 
управлінням. В такому разі автори заперечують здійснення суто управлінського впливу державної влади, сподіваючись на самоорганізацію та самокерованість ОТГ та адміністративний вплив органів місцевого самоврядування, що в нашому розумінні не зовсім відповідає реаліям сьогодення.

Наша позиція відносно питань, піднятих в даних тезах, полягає в наступному. Доки існуватиме держава, доти існуватиме і державне управління. Державне управління перш за все має дбати про національні інтереси держави, відповідати за державну політику та безпеку держави в цілому, стабільність економічної та політичної системи та іiі подальший розвиток в напрямку підвищення добробуту населення та збалансованості дій центральної влади; належний рівень державної інформаційно-комунікативної політики; вживати превентивні заходи щодо можливих загроз кібербезпеці держави, дбати про екологічну безпеку, безпеку об'єктів стратегічного значення; перейматись питаннями збереження держави як такої та запобігати можливим проявам сепаратизму; здійснювати загальне керування всією управлінською інформацією, що стосується питань загальнодержавного рівня.

3 огляду на нинішне внутрішне та зовнішне становище нашої держави, уповільнене просування адміністративних реформ в напрямку децентралізації та нову державну політику, ми вважаємо доречним залишити державні справи разом 3 державним управлінням державі, тобто 3 повноцінним функціонуванням поняття «державне управління», без заміни його на «публічне управління» або «публічне адміністрування».

Органи представницької влади, які наразі проводять свою діяльність, що здебільшого підпадає під визначення терміну «публічне адміністрування» 3 елементами державного управління (виконкоми), мають в основному врегульовувати важливі соціальні питання та здійснювати сервісну діяльність в публічному секторі. Коло управлінських повноважень та компетенцій має бути чітко визначеним та обмежуватися відповідними директивами та постановами уряду.

Висловлюємо припущення, що на сучасному перехідному етапі суспільно-політичних перетворень в Україні було би слушним користуватись в повному їх сенсі двома термінами, а саме - державне управління та публічне адміністрування.

Вважаємо за доцільне переглянути також питання щодо права надання статусу державного службовця з метою його залишення тільки для представників органів виконавчої влади всіх рівнів з урахуванням 
того факту, що законодавча влада представлена депутатами, яких обирає народ. Водночас ми свідомі думки, що деякі судження нашої статті носять дискусійний характер.

\section{Література:}

1. Атаманчук Г.В. Теория государственного управления. Курс лекций, 4-е изд., дополн. /Г.В.Атаманчук. М. Омега - Л. 2006, 584c.

2. Філіпова Н.В. Зміна співвідношень понять «державне управління», «публічне управління» та «публічне адміністрування» у системі суспільно-політичних трансформацій». Журнал. Державне управління:удосконалення та розвиток. 2015. № 6. Дніпровський держ.аграрно-екон.ун-тет. ТОВ»ДКС-Центр».

3. Митяй О.В. Світовий О.М. Дослідження понять «державне управління» i «публічне адміністрування» // Журнал. Держава та регіони. Сер. Держ. упр. 2018. Вип. 1. С. 124-128 